\title{
Republican ecological citizenship in the 2015 Papal Encyclical on the environment and climate change
}

Article

Accepted Version

Hilson, C. (2018) Republican ecological citizenship in the 2015

Papal Encyclical on the environment and climate change.

Critical Review of International Social and Political Philosophy, 21 (6). pp. 754-766. ISSN 1743-8772 doi:

https://doi.org/10.1080/13698230.2017.1315871 Available at https://centaur.reading.ac.uk/69857/

It is advisable to refer to the publisher's version if you intend to cite from the work. See Guidance on citing.

To link to this article DOI: http://dx.doi.org/10.1080/13698230.2017.1315871

Publisher: Routledge

All outputs in CentAUR are protected by Intellectual Property Rights law, including copyright law. Copyright and IPR is retained by the creators or other copyright holders. Terms and conditions for use of this material are defined in the End User Agreement.

www.reading.ac.uk/centaur 
Central Archive at the University of Reading

Reading's research outputs online 


\title{
Republican Ecological Citizenship in the 2015 Papal Encyclical on the Environment and Climate Change
}

Chris Hilson*

School of Law, University of Reading, United Kingdom

\begin{abstract}
The current article explores the treatment of ecological citizenship in the 2015 Papal Encyclical on the environment and climate change, the Laudato Si'. The Encyclical, although rich in its political theory, is (understandably) light in its explicit reliance on academic sources in the area. The article therefore aims to connect the two. In doing so, it argues that the Laudato has significant similarities with civic republican versions of ecological citizenship.
\end{abstract}

Keywords: Ecological citizenship; republicanism; Papal Encyclical; virtues; environment

\section{Introduction}

The 2015 Papal Encyclical, the Laudato Si ${ }^{11}$ (Pope Francis 2015) is addressed not only to Catholics but to everyone: 'faced as we are with global environmental deterioration, I wish to address every person living on this planet' (3). ${ }^{2}$ Pope Francis' Laudato has much to offer those with an interest in environmental political theory. Indeed, whoever wrote the Encyclical would appear, if only indirectly, to have drawn extensively on such theory. However, in a UK academic environment that has become increasingly focused on 'impact', somewhat frustratingly for academics in the field, citations are almost exclusively to bishops' conferences from around the world (which may themselves have been the source of direct reliance on work in environmental political theory). Nevertheless, other than a useful general overview piece in the journal Environmental Politics (O’Neill 2016), a blog post (Barry 2016a) and some good examples of more specialist theological assessment (e.g. Ramage 2015), the Encyclical is yet to receive the academic attention it deserves - particularly from political theorists. In the current article, I intend to focus on what the Laudato has to say on the subject of ecological citizenship - a term that is explicitly (and perhaps surprisingly) used in the document. My aim in the current article is to situate the Encyclical's analysis of ecological citizenship within the academic literature on the topic. In that respect it might therefore be regarded as an attempt to provide the document with some academic footnotes. I argue that its main roots can be traced to republican theories of ecological or green citizenship.

*Email: c.j.hilson@reading.ac.uk 


\section{Republican ecological citizenship}

Although the Encyclical does not explicitly refer to republicanism, the vision of ecological citizenship it offers is very much in tune with civic republican political theory, particularly where the latter has been reshaped along ecological lines.

Republican ecological citizenship stands in particular distinction from liberal environmental citizenship (Bell 2005). Liberal environmental citizenship places an emphasis on individual human rights enjoyed by citizens in relation to the environment. The freedom enjoyed by liberal citizens is the negative liberty of non-interference by other people. In common with other models of ecological or green citizenship (e.g. Dobson 2003), instead of rights, republican ecological citizenship stresses the idea of obligations or duties owed by citizens (Barry 2006, Hilson 2010, Machin 2012). The freedom aimed at for citizens is freedom as non-domination. This goes beyond mere non-interference, recognising as it does that a relationship in which one party is exerting domination over another may fall short of interference and yet still constitute a restriction on their liberty. Freedom as non-domination requires accountability mechanisms to prevent exposure to the exercise of arbitrary power (Pettit 1997).

Republicanism involves citizens coming together as a political community to shape the common good via democratic debate (Cannavò 2016). Sustaining the republic into the future is crucial (Barry 2012) and hence, for ecological republicans, ecological sustainability is likely to form a key element of that common good. Arriving at the common good and providing accountability to prevent domination by powerful interests require republicans to be active citizens. Unlike the typical passivity of liberal rights-holding, the fulfilment of republican citizenship duties also requires active citizenship practice by all members of the community.

However, an emphasis on the common good does not mean that republicanism necessarily privileges a singular, top-down vision of the good life. Liberalism of course famously cherishes the freedom it provides for individual citizens to pursue their particular conceptions of the good. Nevertheless, republicanism is also capable of offering a space for pluralism in this sense. As John Barry has observed 'Republicanism does not demand that private views of the good conform to some standard or master conceptualization, and it is compatible with a variety of views of the good, so long as they do not threaten or undermine the freedoms and practices of the common public/political life of the community' (Barry 2012, p. 258).

For republicans, alongside duties - and helping to encourage the fulfilment of them - come civic virtues. Citizenship education plays an important role in inculcating these virtues (Cannavò 2016). Again, unlike the private self-interest of the liberal citizen, the idea of civic virtues is that they are typically other-regarding habits or dispositions which serve the community interest or public good. For ecological republicans, the relevant virtues are ecological virtues, which are aimed at delivering strong sustainability. Republican virtues and 
duties are not seen as replacements for state regulation (of e.g. the environment), but rather as supplements to it (Cannavò 2012).

However, while republicanism thus requires an active citizenship practice, informed by civic virtues, these need not be compliant virtues, and the practice may be one of contestation or resistance against the state (Barry 2016b). Because freedom as non-domination is crucial to republican political theory, securing citizens from the arbitrary exercise of power may require forms of non-violent direct action. Whereas liberals would frame this as 'civil disobedience', ecological republicans may, in relevant circumstances, see it as an example of republican civic duty.

Republican ecological citizenship encourages us to view citizenship practice not just as a matter for the public sphere but also one for the private (Barry 2006, Hilson 2010).

Republicans are suspicious of the marketization of political relationships involved in forms of clientalism, which view citizens largely as passive consumer recipients of services for which they pay taxes (Barry 2016b). However, although decrying the privatisation of the public sphere, they are not averse to the politicisation of the private sphere. Citizens in the public sphere are not consumers, but consumers in the private sphere can act as other-regarding citizens and not just as self-interested consumers. And while republicanism has typically seen the public sphere as the site for the inculcation of civic virtues and the practice of citizenship duties, ecological republicans believe that the private sphere (of the household and consumption decisions in the market) can also be an appropriate site for ecological virtue and duty (Barry 2006, Hilson 2010).

Finally, ecological republicanism is, as Cannavò $(2012,2016)$ notes, suspicious of capitalism and economic growth and tends to favour the simple life as opposed to the excesses of consumerism. For Barry, it is important that republicanism puts the overall aims and means of the economic system up for contestation and democratic debate as much as any other element of the common good:

we need to ask ourselves a very republican question: why, when democratic politics is based on the important but simple idea that there are a variety of ways to organise the polity and governance structures etc., would we accept that there is only one way (capitalism) or one public policy objective (economic growth) to organize and judge the economy? (Barry 2013)

From an ecological republican perspective, capitalism's inherent need for growth is not only ecologically unsustainable in terms of the earth's carrying capacity, but it is also deeply inequitable and, in the end, works against the idea of human flourishing it is intended to serve (Barry 2013).

We can now turn to explore the extent to which the Encyclical reflects some of these ideas associated with republican ecological citizenship.

\section{The private sphere}


Like ecological republicanism, which stresses the role of virtues and duty in the private as well as the public sphere, the Encyclical similarly sees a place for an 'integral ecology' within the private, domestic sphere. This is said to be 'made up of simple daily gestures which break with the logic of violence, exploitation and selfishness' (230). There is, we are told, 'a nobility in the duty to care for creation through little daily actions' (211). These might involve, inter alia, avoiding the use of plastic, recycling, using less water, avoiding food waste, using public transport or car-pooling, planting trees, and turning off lights.

\section{Environmental education}

Environmental education is stressed, by the Encyclical, as the key to ecological citizenship. It emphasises that such education is too often limited to the provision of information. What is also needed, it claims, is to 'instil good habits' and 'cultivat[e] sound virtues' (211). Just as the mention of virtues has clear echoes of republicanism, so too does the Encyclical's emphasis on the need for 'Education in environmental responsibility' (211). It is important to note that environmental education in the document is not only used in the narrow meaning of formal school or university-style teaching and learning. It is also discussed in the broad sense of educating the public - and especially the young - via the media, the family, the church etc, about the importance of the environment and their disposition towards it. It is in that respect very much linked with pro-environment behavioural change: that is envisaged as the clear aim of environmental education. We all need to become better educated in relation to the environment in order to change our practices.

\section{Ecological virtues}

Like republicanism, the Encyclical argues for the inculcation of civic virtues. The ecological virtues it emphasises include those of sobriety and humility. As it states, 'Sobriety and humility were not favourably regarded in the last century. And yet, when there is a general breakdown in the exercise of a certain virtue in personal and social life, it ends up causing a number of imbalances, including environmental ones' (224). Alongside these virtues, there is also an emphasis on developing those of stillness, restfulness, contemplation, capacity for wonder and for living in the moment and paying attention to others and the beauty of the environment. These are, the document makes clear, in danger of being lost in our distracted, restless, digital and consumption-based age. With a clear dig at the solipsistic smart phone generation, it states that 'Real relationships with others, with all the challenges they entail, now tend to be replaced by a type of internet communication which enables us to choose or eliminate relationships at whim, thus giving rise to a new type of contrived emotion which has more to do with devices and displays than with other people and with nature' (47).

Ecological virtue is distinguished from consumerist vice. Consumerism is characterised as a restless itch to experience more and more which can never be satisfied. The Encyclical recognises that there is a role for the political consumer in the shape of ethical boycotts - in 
other words, as with ecological republicanism, responsibility and citizenship can take place in the private market sphere and not just the public one. In this way, the document has a vision of the consumer as citizen (as opposed to the citizen as consumer). However, broadly speaking, it places consumerism (in the sense of an uncontrolled 'more') as the opposite of ecological citizenship. Instead of the traditional self-interested homo economicus of standard consumerism, it argues for a socially responsible, other-regarding homo civicus operating within the market place. As it states, 'Purchasing is always a moral - and not simply economic - act' (206). What is needed is an ethical consumerism, not an unethical one 'bereft of social or ecological awareness' (219). Just as one might distinguish Islam from Islamism, so the Encyclical effectively distinguishes between the consumer and the ideology of consumerism. The former is not necessarily extreme and can and should be politically motivated as a form of individual agency in the private sphere. The latter is an extreme structural pathology of our time and humans who are subject to its spell are encouraged instead by the Encyclical to seek real spiritual fulfilment through exposure to nature and everyday acts of generosity, kindness, stillness and contemplation. Consumerism holds out the promise of pleasure and happiness, but its ideology involves an obsessive search by people for the next thing or experience that they do not have and for an ever increasing 'accumulation of pleasures' (222). And when those things or experiences are consumed, they are often ultimately unable to provide the anticipated fulfilment because they are typically empty of spiritual content. We should instead, according to the Encyclical, be spiritually detached from our possessions.

The paper's negative views of consumerism are, as we saw earlier, very much shared by green republicanism. Its emphasis on non-material experiences (stillness, contemplation etc) is also in tune with ecological republicanism and other strands of green political thought, which regard such experiences as a more promising route to wellbeing than the materialism of consumer society, with its reliance on GDP as an inadequate proxy for human happiness. ${ }^{3}$ The Encyclical emphasises that it is the excess involved with 'extreme' or 'compulsive' consumerism which is harmful (203). As it observes, 'A constant flood of new consumer goods can baffle the heart and prevent us from cherishing each thing and each moment' (222). However, (political consumerism aside) it perhaps does not do enough to avoid throwing the baby out with the bathwater. The Encyclical could have mentioned the British Arts and Crafts Movement tradition as exemplified by the thinking of John Ruskin and William Morris. While equally against the excesses of consumerism centred on mass production, it saw a place for the limited consumption of hand-crafted, beautiful objects that were necessary in the home. For the Arts and Crafts Movement, the dignity of craft labour dignity all too often missing for the factory worker - was reflected in the quality of the final product. This form of production and consumption ought, one might argue, to have been acknowledged by the Encyclical, which seems reluctant to recognise that there can be any form of spiritual nourishment or aesthetic appreciation in the consumption and use of domestic, everyday things. ${ }^{4}$

The paper's critique of consumerism can be linked with its espousal of green republican arguments about Limits to Growth. It underlines these limits in both spiritual and physical 
terms. Regarding the former, it suggests that 'Christian spirituality proposes a growth marked by moderation and the capacity to be happy with little' (222). In relation to the latter, it points to the non-infinite supply of resources (106) and also the planet's inability to cope with the waste products of ever-increasing consumption (50). It therefore advocates containing growth. However, mindful of the injustice of denying the development needs of those 'not yet able to live in a way worthy of their human dignity' (193), the Encyclical argues for something akin to a contraction and convergence model of equitable growth. This involves those who currently over-consume having to limit consumption, while the poor are allowed space to increase theirs.

The Encyclical's critique of consumerism and unbridled growth goes hand in hand with what can be characterised as an 'anti-capitalist' or at the very least capitalist-sceptic tone - again, something the encyclical shares with green republicanism. The paper questions, inter alia, the idea of profit maximisation and ever increasing production $(109,195)$. It expresses doubts over whether ecological modernisation, which maintains 'that current economics and technology will solve all environmental problems' (109), will be sufficient to redirect the economic system in the way that is needed. That direction should be towards 'more balanced levels of production, a better distribution of wealth, concern for the environment and the rights of future generations' (109). It is, nevertheless, sceptical about whether our current, short-termist electoral cycles are capable of changing direction, as 'governments are reluctant to upset the public with measures which could affect the level of consumption or create risks for foreign investment' (178). In tune with republicanism, which as we have seen emphasises the long-term continuation of the Republic through time, the Encyclical makes a case for 'true statecraft', which upholds high principles in difficult circumstances with an eye on what is in the long-term common good (178).

The Encyclical effectively raises two key questions regarding its republican-inspired ecological virtues. First, does our ontological relationship with nature have to change in order to inculcate these virtues? And second, what is the telos of the ecological citizenship virtues? Beginning with the first issue of whether a change in our attitude to nature is required, the document does not argue for an altogether changed ontology away from current anthropocentrism. The relationship with nature advocated is not the extreme anthropocentrism of 'dominion' often preached by the Church in the past, which involved human mastery over nature, because this is said to undervalue nature and God's love and concern for it. However, neither is it biocentrism and the intrinsic value of nature, because it claims that this undervalues human uniqueness. The Encyclical instead argues that a new more respectful relationship with nature can lead us to cultivate ecological virtues because God is present in nature. Christians will be motivated to develop such virtues because their relationship with nature is one in which they can see God's creation and a desire to serve or honour God involves taking care not to despoil what remains dear to him. The idea of dominion is effectively replaced by one of 'responsible stewardship' (116). Because the earth is God's creation, humans have no right to abuse it, but rather owe a duty as stewards to look after it and to pass it on in a healthy state to the next generation. The aim of the Encyclical is thus to reverse the 'dominion' view which tells us that the earth was made for humans and to 
say instead that we are made for the earth, where the earth is God's creation and the collective patrimony of the human species to be passed on to future generations (Barry 2016a). We honour and praise God by looking after, not despoiling the earth, 'our common home' (1).

This part of the document is obviously limited to Christianity and other religions which see God's hand in nature or, like paganism, view nature as God. ${ }^{5}$ For present purposes though, what is more universally worthy of note is what it says about the link between a changed ontology and ecological citizenship virtues. As Table 1 below shows, the Laudato is effectively arguing that a changed, more reverential relationship with nature (albeit still an anthropocentric one) is sufficient to cultivate ecological virtues but is not necessary: a true Christian attitude to nature would lead one to such virtues, but the Encyclical does not exclude other possible routes to their inculcation.

In his work on virtues and environmental citizenship Connelly (2006), in contrast, claims that it is asking too much to wait for large numbers of people to change their ontological approach in this sense (even if only relatively mildly in the Encyclical's case and not all the way to biocentrism or deep ecology). He also emphasises that it is not necessary for developing environmental virtues, believing that these can be encouraged without such a re-orientation. Hannis (2015), in his recent book on freedom and the environment, adopts a different position again. Echoing Barry (2012), he argues that some form of acknowledgement of human ecological dependence and a sustainable common good should be seen as part of human flourishing and the good life in an Aristotelian, virtue ethics sense.

Table 1 sets out the different approaches in play here. It is worth distinguishing between the views of the three - the Pope, Connelly and Hannis - on our relationship with nature and whether this needs to change on the one hand and, on the other, the telos or end point of the ecological citizenship virtues. ${ }^{6}$ In relation to the telos of virtues, this can either be externally directed, in the service of sustainable development, or it can be internally focused on producing human flourishing (Connelly 2006).

\section{[INSERT TABLE 1 HERE]}

Hannis claims that both a changed relationship and ecological virtues are necessary for reasons of human flourishing. On the former, he states that this need not 'require an ecocentric "deep ecologist ontology"' (Hannis 2015, p. 173). Instead, drawing on Barry and MacIntyre, he argues for an acknowledgement of 'ecological dependence' (p. 160), claiming that 'the development of ecological virtue rel[ies] on proper understanding of the complex dependencies and interdependencies involved in human life and agency' (p. 160). Regarding the latter (virtues), on his view one cannot separate ecological virtues from human flourishing as an end. If the ecological virtues are not perceived as personally rewarding in a flourishing sense, then why would people bother practising them? He claims that people are all the more likely to be engaged with the virtues if they are also said to promote individual flourishing. In other words there becomes a self-interested as well as an other-regarding reason for virtuous practice. ${ }^{7} \mathrm{He}$ also takes issue with regarding sustainable development as an external telos, 
arguing instead that a sustainable environment is a key component of individual human flourishing (and hence represents an internal telos).

For Connelly, to advocate the development of a changed ontology is to follow an unnecessary blind alley. He also believes that ecological virtues are needed not as Hannis argues, for reasons of human flourishing, but rather because these are instrumentally useful for achieving sustainability as an independent or external telos. In other words, ecological virtues can be a means towards sustainability as an end, and individual human flourishing need not also be an end of practising such virtues.

As regards the Encyclical, we have seen that this does not state that a changed relationship with nature is necessary for the inculcation of ecological virtues but that it is sufficient; it also argues that Christians should adopt such a change both because it is important for human flourishing and for sustainability reasons. In this respect it is something of a combination of Connelly's and Hannis' approaches. It is less categorical than either in terms of the link between ontological change and ecological virtues. It also places the two possible ends of ecological virtues alongside each other: such virtues become not just about instrumentally securing improved environmental conditions as an external telos but also about ensuring human flourishing as an internal one. It is of course not surprising that the Church would have something to say about human flourishing as a telos.

\section{Ecological citizenship and the state}

Another interesting area to consider is the Encyclical's treatment of the relationship between ecological citizenship and the state. On the one hand, it its criticism of the excesses of free markets and capitalism, it clearly envisages a role for the state which involves regulation:

The limits which a healthy, mature and sovereign society must impose are those related to foresight and security, regulatory norms, timely enforcement, the elimination of corruption, effective responses to undesired side-effects of production processes, and appropriate intervention where potential or uncertain risks are involved. There is a growing jurisprudence dealing with the reduction of pollution by business activities. (177)

This regulation, it argues, must not just be a matter of avoiding bad practice, but also promoting best practice (177). However, at the same time - and with clear echoes of green republicanism - the Encyclical expresses scepticism about what it sees as a tinkering role for the state. What is needed, it claims, is bold thinking which reaches beyond regulatory solutions to get to the underlying systemic problems which are the real cause of environmental degradation:

A strategy for real change calls for rethinking processes in their entirety, for it is not enough to include a few superficial ecological considerations while failing to question the logic which underlies present-day culture. (197) 
As for the relationship between citizens and the law, the paper observes that, particularly in countries with low levels of institutional effectiveness, 'a lack of respect for the law is becoming more common' (142). This means that 'Laws may be well framed yet remain a dead letter' (142). Environmental legislation (e.g. to protect forests) will prove ineffective if the authorities turn a blind eye to its infringement, failing to enforce it in practice. However, what is really needed, it argues, is for the majority to internalise environmental norms without there being a need to rely on imposing sanctions:

The existence of laws and regulations is insufficient in the long run to curb bad conduct, even when effective means of enforcement are present. If the laws are to bring about significant, long-lasting effects, the majority of the members of society must be adequately motivated to accept them, and personally transformed to respond. (211)

It goes on to state that 'we need institutions empowered to impose penalties for damage inflicted on the environment. But we also need the personal qualities of self-control and willingness to learn from one another' (214). This can be read either as effectively reiterating the paragraph quoted above, with legislation reliant on underlying personal qualities, or as making a wider case for voluntary behavioural change as a necessary, separate supplement to legislative control.

To locate this in republican terms, one might put it as follows. A good ecological citizen generally complies with the law (and does so in a way that internalises it without the need for sanctions to be applied). Nevertheless, this is not always the case, or rather it applies only in relation to laws which are protective of the environment. There is an important role for civil disobedience in republican ecological citizenship (Barry 2006, 2012) - i.e. there may be occasions where a good ecological citizen has a moral duty to break a law which threatens the environment. The good ecological citizen also goes beyond the law, adopting, on a voluntary basis, responsible, pro-environment behaviour which is not required by the law (but which, in republican and also Dobson's (2003) post-cosmopolitan ecological citizenship, may at times nevertheless be regarded as a moral and political duty of justice). As we have seen above, this is likely to require the development of environmental virtues. Importantly, both are needed. Legislation by itself, without ecological citizenship to support and supplement it, is likely to be insufficient. But equally, because of collective active problems and the risk of free-riding, ecological citizenship alone without legislative coercion will also be inadequate to the task of addressing our environmental problems.

Nevertheless, as Melo-Escrihuela (2008) and Scerri ((2012) observe, there is a risk, inherent in ecological citizenship, of depoliticising and privatising green issues and hence paying insufficient attention to the wider socio-economic structural causes of environmental degradation and injustice. According to Scerri, 'the new citizenship ... deepens the individuation of ethico-moral reflection while depoliticizing the production-consumption chains that, in practice remain sources of the ethico-moral dilemmas that green consumption is set to resolve' (Scerri 2012, p. 133). For green republicans, as we have seen, deeper changes in state practice are needed. The aim should be not just to regulate the environmental 
pathologies of the current economic system via legislation, but to tackle the root causes of those pathologies in that system. However, while alive to the risk of depoliticisation, green republicans share the Encyclical's view that we should not talk ourselves out of adopting voluntary action. As it states:

We must not think that these efforts are not going to change the world. They benefit society, often unbeknown to us, for they call forth a goodness which, albeit unseen, inevitably tends to spread. Furthermore, such actions can restore our sense of selfesteem; they can enable us to live more fully and to feel that life on earth is worthwhile. (212)

In the end, ecological citizenship is important and so too is the state. And the relationship between the two is also key: the temptation is to focus on the voluntary elements of ecological citizenship without considering the way in which the good ecological citizen responds to the law.

\section{Conclusion}

The Encyclical contains a sophisticated treatment of ecological citizenship which is, nevertheless, somewhat unconnected from the exiting academic literature on the area, at least in terms of explicit citation. That lightness in displaying its learning is of course understandable. It is not a matter of academic carelessness but rather one of authority. While academics like to be cited, especially by those with power, in the case of a Papal Encyclical one can understand a desire to keep its worldly roots somewhat obscured. Citing academics, who may in other respects hold vastly different worldviews to Catholic teaching, could be regarded as a risky strategy: much safer then (and more inclusive in Church terms) to rely as your authority mostly on bishops' conferences.

I have argued that what the Laudato has to say on ecological citizenship has much in common with academic writing on the topic in the republican tradition. This is particularly the case in relation to its emphasis on notions of duty, responsibility, justice and virtues, and also in its discussion of citizenship practice in the private sphere. What is of course important in the end though is that our harmful environmental practices change. The fact that the Encyclical is likely to be read by many Catholics and used to inform the religious instruction of many others provides hope that it may make a contribution towards this. Some have questioned whether it provides enough of a blueprint for action. ${ }^{8}$ In reality, the main change it provokes is likely to be in individual dispositions and behaviour. This is both its strength and, ultimately, its weakness. The blueprint it provides is for ecological citizenship practice. However, the broader political change it also convincingly argues for lacks a clear blueprint for what is needed to replace our current, troubled system and how to get there. 
Table 1: Ecological virtues, ontological change and telos

\begin{tabular}{|l|l|l|l|}
\hline & Connelly (2006) & Hannis (2015) & Encyclical (2015) \\
\hline $\begin{array}{l}\text { Is Ontological } \\
\text { Change needed to } \\
\text { inculcate virtues? }\end{array}$ & No & Yes & $\begin{array}{l}\text { Not necessary but is } \\
\text { sufficient (and } \\
\text { Christians should) }\end{array}$ \\
\hline Telos of virtues & $\begin{array}{l}\text { External - sustainable } \\
\text { development }\end{array}$ & $\begin{array}{l}\text { Internal - individual } \\
\text { human flourishing } \\
\text { (albeit that a } \\
\text { sustainable } \\
\text { environment is a key } \\
\text { component of such } \\
\text { flourishing) }\end{array}$ & $\begin{array}{l}\text { External and internal } \\
\text { - sustainable } \\
\text { development and } \\
\text { human flourishing } \\
\text { (211-212) }\end{array}$ \\
\hline
\end{tabular}

\section{Acknowledgements}

I am grateful, for their comments, to the anonymous referee and to those present at the roundtable, 'Environmental Implications of the Laudato Sì', organised by the Foundation for Law, Justice and Society in association with the Centre for Socio-Legal Studies, University of Oxford, Worcester College, 2016.

\section{Disclosure statement}

No potential conflict of interest was reported by the author.

\section{Notes}

\footnotetext{
${ }^{1}$ This translates as 'Praise be to you' and, analogising with the Earth, reflects the words of a canticle in which Saint Francis of Assisi speaks of our common home being like a sister with whom we share our life and a mother who embraces us with open arms.

${ }^{2}$ References to the Laudato throughout are to paragraph numbers and, for ease of reference, are not preceded by Pope Francis' name as author.

${ }^{3}$ As the Encyclical states 'Frequently, in fact, people's quality of life actually diminishes - by the deterioration of the environment, the low quality of food or the depletion of resources in the midst of economic growth' (194).

${ }^{4}$ Whereas it does acknowledge the ability of 'technoscience' to 'produce art and enable men and women immersed in the material world to "leap" into the world of beauty' by constructing non-domestic, major engineering products. Of these, it says, 'Who can deny the beauty of an aircraft or a skyscraper?' (103).

${ }^{5}$ The Papal view is expressly not the latter, commenting that 'This is not to forget that there is an infinite distance between God and the things of this world, which do not possess his
} 
fullness' (88). That said, the mystic's position comes close: 'This is not because the finite things of this world are really divine, but because the mystic experiences the intimate connection between God and all beings, and thus feels that "all things are God"' (234). See further Ramage (2015).

${ }^{6}$ Of course the two could in theory be connected if one regards the former as itself a type of virtue.

${ }^{7}$ This is compatible with certain readings of civil republicanism (e.g. Barry 2012), whereby ecological citizenship can be seen as both instrumentally valuable (external) and intrinsically valuable as an end in itself (internal).

${ }^{8}$ See e.g. Barry (2016a), who states: 'the pope has offered some beautiful provocative ideas ... What are the actions that follow? Or and here reverting to my lapsed Marxist-Lentilist collapsed Catholicism - what is to be done?'

\section{Notes on contributor}

Chris Hilson is a Professor of Law in the School of Law, University of Reading, UK. He has written extensively on green and EU citizenship, EU environmental rights, and EU identity. His other recent work has been in the area of climate change litigation, and law and social movements.

\section{References}

Barry, J., 2006. Resistance is fertile: From environmental to sustainability citizenship. In: A. Dobson and D. Bell, eds. Environmental citizenship. Cambridge, MA: MIT Press, 21-48.

Barry, J., 2012. The politics of actually existing unsustainability: Human flourishing in a climate-changed, carbon constrained world, Oxford: OUP.

Barry, J., 2013. Post-growth: a green republican economy. openDemocracy [online]. Available from: https://www.opendemocracy.net/ourkingdom/john-barry/post-growth-greenrepublican-economy [Accessed March 2017].

Barry, J. 2016a. Marxist-Lentilist thoughts on Pope Francis's encyclical letter laudato 'si on care for our common home [online]. Available from:

https://www.academia.edu/26877990/Marxist-

Lentilist_Thoughts_on_Pope_Franciss_Encyclical_Letter_Laudato_Si_onCare_for_Our_Co mmon_Home [Accessed March 2017].

Barry, J., 2016b. Citizenship and (un)sustainability: A green republican perspective. In: S.M. Gardiner and A. Thompson, eds. The Oxford handbook of environmental ethics. Oxford: OUP, 333-343.

Bell, D.R., 2005. Liberal environmental citizenship. Environmental politics, 14 (2) 179-194. 
Cannavò, P., 2012. Ecological citizenship, time and corruption: Aldo Leopold's green republicanism. Environmental politics, 21 (6) 864-881.

Cannavò, P., 2016. Environmental political theory and republicanism. In: T. Gabrielson, C. Hall, J.M. Meyer, and D. Schlosberg, The Oxford handbook of environmental political theory, Oxford: OUP, 72-88.

Connelly, J., 2006. The virtues of environmental citizenship. In: A. Dobson and D. Bell, eds. Environmental citizenship. Cambridge, MA: MIT Press, 49-73.

Dobson, A., 2003. Citizenship and the environment. Oxford: OUP.

Hannis, M., 2015. Freedom and environment: Autonomy, human flourishing and the political philosophy of sustainability. New York: Routledge.

Hilson, C., 2010. EU environmental solidarity and the ecological consumer: Towards a republican citizenship. In: M. Ross and Y. Borgmann-Prebil, eds. Promoting solidarity in the European Union. Oxford: OUP, 136-150.

Machin, A., 2012. Decisions, disagreement and responsibility: towards an agonistic green citizenship. Environmental politics, 21 (6), 847-863.

Melo-Escrihuela, C., 2008. Promoting ecological citizenship: Rights, duties and political agency. ACME , 7 (2), 113-134.

O’Neill, E., 2016. The Pope and the environment: Towards an integral ecology?

Environmental politics, 25 (4), 749-754.

Pettit, P., 1997. Republicanism: A theory of freedom and government. Oxford: OUP.

Pope Francis, 2015. Laudato Si': On care for our common home. Rome: Vatican.

Ramage, M.J., 2015. Integral ecology and the ecological virtues in Pope Francis's laudato si'. Homiletic and pastoral review [online]. Available from:

http://www.hprweb.com/2015/11/integral-ecology-and-the-ecological-virtues-in-popefranciss-laudato-si/ [Accessed March 2017].

Scerri, A., 2012. Greening citizenship: Sustainable development, the state and ideology. Basingstoke: Palgrave Macmillan. 